Reprod. Nutr. Dévelop., 1980, 20 (1 B), 349-375.

\title{
Growth as affected by general hormonal factors and hormonal balances, and the limitations of such studies
}

par L. DAUZIER

Station de Physiologie animale, I.N.R.A.

E.N.S.A., place Viala, 34060 Montpellier cedex France.

Summary. Many elements are implicated in fetal and postnatal growth ; the hormonal factors are discussed in this review. In the first section, general hormonal effects on the growth of domestic animals are reviewed with special emphasis on the role of the pituitary and its hormones (growth hormone, prolactin, $A C T H$ ) ; somatomedin action is considered in this perspective. The effects of the thyroid and its hormones, the adrenal cortex and corticosteroids, gonads and sex steroids and insulin are discussed.

In the second part of this review, the problem of hormonal balance and growth during fetal and postnatal life is analyzed. The complementarity of the « growth activities 》 of the growth hormone $(\mathrm{GH})$ and the placental somatotropic or lactogenic hormone (CS or PL) during fetal life is emphasized. The relations between these hormones, somatomedins and fetal development are reviewed in detail : thyroid hormones and estrogens as well as insulin may also play a role in fetal development.

In neonatal life the correlations between plasma hormone concentrations and growth are more or less strict. These levels depend on the kinetic factors of hormone metabolism whose correlation to growth has been studied. The mode of action of some hormonal treatments and the effect of selection on some hormonal balances are also discussed.

In the third part of this report, a critical study indicates the limitations in investigations on growth endocrinology. Special attention has been given to the problem of hormone level fluctuations in relation to plane of nutrition, stress, light/dark cycle, as well as to the paucity of data on growth peptides and the limitations of assay methods.

\section{Introduction.}

Fetal and postnatal growth depends on many elements, some of which, such as nutrition and genetic factors, rearing conditions and hormones, play a key role. In this report, we only consider the hormonal factors, emphasizing the correlations and interrelations between hormone levels or some parameters of their patterns, and certain aspects of the growth and development of domestic animals.

\section{1. - General hormonal effects on the growth of domestic animals}

Without studying in detail the effects of all the hormones, their role was first evidenced by many experiments on endocrine gland excision. 
Pituitary gland and its hormones. The effects of hypophysectomy vary with breed and age at the time of the operation.

In the chicken, early hypophysectomy after hatching causes a high mortality, and at 50 days slows down ponderal growth (Goussopoulos, 1978). If carried out later, animal growth is also retarded but prolonged beyond that of the controls, so that the operated animals catch up to, or even exceed, the controls.

During fetal life, hypophysectomy does not cause an arrest of growth in the rabbit (Jost, 1947) or the sheep (Liggins and Kennedy, 1968 ; Barnes et al., 1976). After birth, pituitary regulation of ponderal growth in the rabbit only reaches its full efficiency from about 100 days onwards (Vezinhet, 1968b). In the lamb, this regulation occurs earlier because hypophysectomy causes growth to stop at 25 days of age (Vezinhet, $1968 a, 1976)$. However, these effects on ponderal growth give no indication of the relative development of different tissues.

In the species studied in which hypophysectomy is performed after birth, the adipose deposits increase spectacularly relative to the liveweight, and their development in relation to the total adipose mass is similar in the controls and the operated animals, except for the perirenal deposits which develop relatively more after the operation in the lamb and rabbit (Vezinhet, 1976). As concerns other tissues, hypophysectomy usually slows down skeletal development, while the relative growth of the muscular mass is either retarded in the chicken and before 100 days in the rabbit, or arrested in the rabbif after 100 days and in the lamb (Vezinhet, 1976). The quantity of DNA ceases to increase in the hypophysectomized rabbit, indicating an arrest of muscle nucleus multiplication (Cordesse, 1979).

Some of the differences in the tissular development of hypophysectomized animals as compared to the controls evidence the effects of the operation on metabolisms.

Thus, the adiposity of hypophysectomized rabbits is due rather to a decrement of lipolysis than to increased lipogenesis. Reduced lipolytic activity in the lamb may even compensate for a slowing down of lipogenesis (Vezinhet, 1976).

These effects of hypophysectomy could result either from the direct effects of some pituitary hormones or from the decreased secretion of pituitary-dependent endocrine glands.

Among these hormones, pituitary GH or growth hormone is particularly interesting. A chronic treatment of bGH (bovine growth hormone) clearly improves the weight gain of hypophysectomized lambs, being about that of the controls (Vezinhet and Dauzier, 1970 ; Vezinhet, 1976). In these lambs, bGH reesłablishes muscular and bone growth similar to that in normal animals, and it considerably reduces adipose stores. On the other hand, bGH has no effect on the ponderal growth of normal lambs (Vezinhet, 1973).

In hypophysectomized rabbits older than 100 days, bGH is inactive for reasons which may be imputed to its specificity. In fact, pGH (porcine growth hormone), which is similar to rabbit $\mathrm{GH}$, tends to reduce the adipose stores of the hypophysectomized rabbit (Vezinhet, 1976). These lipolytic effects are seen in vivo after acute bGH treatment of lambs and pGH treatment of rabbits ; on the other hand, bGH used on rabbits does not triggor a release of the free fatty acids in the blood.

PGH in vitro has also proved to be lypolytic on rabbit adipocytes. On the contrary, bHG shows no lypolytic action in vitro on either rabbit or lamb adipocytes (Vezinhet, 
1976). The data obtained in vitro on rabbit adipocytes with $\mathrm{PGH}$ demonstrate that $\mathrm{GH}$ has a direct effect on adipose tissue. Its direct effect is also evident on hepatic tissue, which has GH membrane receptors (Tsushima and Friesen, 1973), and on muscle tissue where it initiates protein synthesis (Kostyo and Knobil, 1959).

On the other hand, $\mathrm{GH}$ would have no direct effect on cartilaginous or bone tissues, although it stimulates their growth, since biological GH assay is carried out by measuring the increase in thickness of the proximal epiphyseal cartilage of the hypophysectomized rat tibia (Greenspan et al., 1949). The influence of $\mathrm{GH}$ on the cartilage or bone acts through hormonal mediators, the somatomedins (Daughaday ef al., 1972), whose formation is triggered by hepatic $\mathrm{GH}$ and, to a lesser extent, by renal GH. These somatomedins have been mostly studied in humans and rats, but act on pig cartilage and the embryonic chick pelvis used in their assay. They influence bone growth by inducing sulfate incorporation into proteoglycans and DNA, RNA and protein synthesis, and also stimulate muscle protein synthesis and glucose oxidation in rat adipose tissue. Their effect in vitro is antilypolytic instead of lipolytic as GH. Somatomedins have a more marked effect on muscle and liver in vitro than $\mathrm{GH}$, which must be used at high doses.

Finally, a placental hormone having a twofold activity (lactogenic and somatotropic) has been isolated in the pregnant females of some species (humans, cattle, sheep). Studying the pregnant ewe, Martal and Djiane (1977a) isolated oPL (ovine placental lactogen hormone) still called oCS (ovine chorionic somatotropin or somatomammotropin). oCS acts on bone growth and increased the liveweight gain of hypophysectomized rats (Martal and Djiane, 1977a; Martal, 1978).

Besides somatotropic hormones, prolactin has been found to have some anabolizing properties when injected into rats, increasing the weight of puberal females (Reisfeld et al., 1961 ; Bates et al., 1964), and augmenting protein synthesis in the diaphragm of hypophysectomized rats incubated in vitro (Hamid et al., 1965). It may be implicated in the effects of photoperiodism on bovine and ovine growth. In fact, when a rather high ambient temperature is maintained, heifers reared under a light/dark cycle of 16 L-8 D grow more rapidly than animals under a natural light/dark cycle (Peters ef al., 1978). Also, lambs reared under long daylength of $16 \mathrm{~L}-8 \mathrm{D}$ have a significantly higher growth rate than those raised under short daylength $(6 \mathrm{~L}-16 \mathrm{D})$ (Driver ef al., 1976). It is interesting to note that animals raised under a long daylight ratio have a higher serum prolactin concentration (sheep : Pelletier, 1973 ; Forbes et al., 1975 ; cattle : Peters and Tucker, 1978) and the same serum GH content (sheep : Driver et al., 1976 ; cattle : Peters and Tucker, 1978) as slower-growing animals reared under a shorter daylight ratio.

Contrary to $\mathrm{GH}$, prolactin has no effect on serum free fatty acids or aminoprotein concentrations in cattle and sheep (Manns and Boda, 1965).

Besides stimulating the adrenal cortex, ACTH has a distinctly lipolytic effect in the rabbit, and according to Desbals (1962), it would be the typical lipolytic hormone of that species. Other than its considerable action on lipid metabolism, ACTH would affect carbohydrate metabolism by inducing hypoglycemia and hepatic neoglucogenes apparently by triggering insulin secretion (Desbals, 1967).

The pituitary may also act indirectly by mediating the activity of some endocrine glands. 
The thyroid and its hormones. Thyroidectomy of the sheep fetus retards growth and ossification, development of the skeleton and secondary skin follicles and causes muscular weakness (Erenberg ef al., 1974 ; Thorburn, 1974); the young are born alive but live only a short time. Administration of an antithyroid drug, methyl thiouracil, to pregnant ewes causes not only prolonged pregnancy, but the birth of dead lambs smaller than the controls (Lascelles and Setchell, 1959). Thyroidectomy in the rabbit fetus does not stop growth before day 29 of pregnancy, but it increases body fat (Jost, 1977). Thyroidectomy after birth also retards the growth of lambs (Falconer and Draper, 1968) and calves (Spielman ef al., 1944).

Thyroid hormones are necessary for tissue differentiation and especially for maturation of the brain and the skeleton ; the effects of thyroidectomy thus depend on when the operation is done, and also on when these tissues differentiate. During the postnatal period, thyroid deficiency retards the growth of almost all the organs, causing a more or less important arrest of development. Thyroid hormones are also involved in muscle growth, and initiate protein synthesis, particularly of myosin (Flaim et al., 1978).

The adrenal cortex and corticosteroids. An excess of glucocorticoids is usually associated with retarded growth (Daughaday et al., 1975).

The glucocorticoids have a catabolizing effect on muscle protein, resulting in an increase of serum amino acids, especially alanine and glutamine. Corticoids act mainly on white muscle fibers, 3-methyl histidine being for some authors an indicator of this muscle protein degradation (Mayer and Rosen, 1977). The corticosteroids would be GH antagonists, slightly inhibiting GH action on somatomedin formation (Daughaday et al., 1975).

Glucocorticoids also show lipolytic activity in vivo and in vitro, but, as noted by Davies (1973), authors have obtained varying results on response intensity.

Daughaday et al. (1975) studying cartilage, reported that glucocorticoids caused a decrease in the number and size of chondrocytes as well as some cellular disorganization.

Some authors using chronic glucocorticoid treatments on sheep and cattle have shown a significant increase in weight gain ; others reported no effect. Carcass composition would show a decrease in protein content and an increase in fat (Spurlock and Clegg, 1962 ; Clark et al., 1963 ; Carroll ef al., 1963 in bull calves). This increase in adiposity could be due to hyperglycemia and hyperinsulinemia caused by the injections (Bassett and Wallace, 1967 ; Bassett, 1968).

Gonads and sex steroids. Castration has been practised since the beginning of animal domestication.

The growth rate of steers is lower than that of bulls, the difference varying with the breed, rearing conditions and plane of nutrition (Turton, 1969). The same is true of carcass yield and feed efficiency; weight gain composition would tend to be richer in meat and bone and poorer in fat in intact males. Moreover, these animals would have more large-fiber muscle richer in connective tissue than the castrates. The differences vary with the muscle, the development of some being considered a secondary sex character.

Studies on sheep were mostly carried out by Hammond and his collaborators 
(1932), who obtained results similar to those cited above : higher liveweight gain, more muscular and skelefal development and less adiposity in intact than in castrated males. Turton (1969) studying pigs also showed a more rapid ponderal growth in intact than in castrated males ; their carcass characteristics resembled those mentioned for cattle and sheep, but boar meat palatability was a problem.

As concerns sex hormones, the anabolizing role of androgens is well known in the rat through the works of Scow (1964), Kochakian $(1965,1966)$ and Krieg and Voigt (1976). Besides accelerating growth and skeletal maturation in rats, androgens induce more muscular development with increased protein synthesis and lower muscle protein catabolism ; they would be glucocorticoid antagonists (Mayer and Rosen, 1977).

On the other hand, estrogens have an anabolizing effect in rats, tending to slow down ponderal and skeletal growth ; after $\mathrm{GH}$ treatment they inhibit the increment of plasma somatomedins.

The data on ruminants are quite different, the androgens producing disappointing results (Rombauts, 1974) although known for their anabolizing effects in rats. Testosterone given alone proved to be a mediocre growth factor. Other androgens, such as methyl androstenediol, were more active, having a stronger effect on heifers than on castrated males. Testosterone had a clear anabolizing effect however when associated with estrogens. Trienolone acetate or R $1697\left({ }^{1}\right)$, an intermediate steroid between estrogens and androgens, proved to be efficient on culled cows (Beranger and Malterre, 1968). Therefore, results differed with the hormone type and the sex of the animal treated.

Estrogens, such as diethylstilbestrol and hexestrol, have been used in stock raising for a long time (at least when the legislation permits it). Diethylstilbestrol given by implant or orally improves liveweight gain, protein retention and the feed conversion ratio in the following decreasing order in cattle and sheep : castrated females, females, intact males, suckling young on which the effects are uncertain (Burgess and Lamming, 1960). The growth rate in pigs is little affected, but the carcasses are slightly leaner and boar taint is strongly inhibited (Plimpton ef al., 1971).

On the contrary, the results obtained with natural estrogens, such as estradiol, are less convincing. Among the progestagens, malengestrol acetate is somewhat efficient on heifers and cows but not on males or castrated females (Bloss et al., 1966). Estrogenprogesterone and estrogen-testosterone combinations are the most efficient.

Aside from the hormones mentioned above, an anabolizing hormone, insulin, induces muscle proteinogenesis (Manchester, 1970), stimulates lipogenesis and shows antilipolytic activity, the overall result on adipose tissue being an increase of adipocyte triglyceride storage. These effects are less evident in ruminants in which volatile fatty acids are essential metabolites. Insulin also stimulates ponderal and linear growth in the hypophysectomized rat (Salter and Best, 1953). This weight increment would mostly result from fat accumulation, but also from increased protein retention. Moreover, insulin is necessary if $\mathrm{GH}$ anabolizing action is to be effective (Daughaday ef al., 1976). To illustrate this, babies of diabetic women frequently have a high weight, indicating that insulin may play a role in fetal growth.

(1) $17 \beta$ acetoxy-3 oxo 4,9 (10) 11 (12) estratriene. 
Following the observations of Honnebier and Swaab (1974) on the rat fetus, some authors have attributed a role to $\mathrm{MSH}$ (melanocyte-stimulating hormone) in growth.

\section{II. - Hormonal balance and growth}

The interrelations among hormonal concentrations, the patterns of their secretion and degradation and some factors of growth, differ before and after birth.

\section{1. - During fetal life.}

Martal (1978), experimenting with sheep, shows close correspondance between fetal weight and the sum of $\circ \mathrm{GH}$ and $\mathrm{OCS}$ « growth activities » because the total plasma oGH and oCS concentrations remain constant at about $200 \mathrm{ng} / \mathrm{ml}$ from day 60 of fetal life (Martal, 1979). At first, oCS " growth activity » is predominant since it appears from day 16-17 in the trophoblasts (Martal and Djiane, 1977). The fetal plasma oCS concentration then increases, reaching a maximum towards day 120 of fetal life (Djiane and Kann, 1975). $\mathrm{OGH}$ appears later in the pituitary and the fetal plasma at about day 50 (Stokes and Boda, 1968). Its plasma concentrations increase to reach a maximum between days 130 and 140 of fetal life (Bassett et al., 1970, 1973 ; Alexander ef al., 1974 ; Bassett and Madill, 1974 ; Gluckman et al., 1979). Thus, while at day 60 « fetal growth activity » is predominantly oCS, at day 120 plasma oGH concentration is about one-third that of oCS and at birth it is about one-half (Martal, 1979). Fetal oGH is secreted by the fetal pituitary and does not originate from the pregnant ewe.

The balance of the two hormones is quite different in the dam and the fetus. In fact, in the pregnant cow and ewe, plasma GH is much lower than in the fetuses (Oxender ef al., 1972 ; Bassett et al., 1970 ; Gluckman et al., 1979) ; on the other hand, there is about 200 times more CS than GH. The plasma oCS pattern provides a simple and rapid diagnosis of pregnancy and twinning in the ewe at day 110 of pregnancy (Clauser, 1979).

Somatotropic fetal pituitary cells are observed from day 67 of fetal life in cattle and from day 30 in pigs (Dubois, 1971).

Cs, which has growth and lactogenic activity, is found in pregnant ruminant and primate females, but is absent in other species such as the pig, dog and cat (Martal, 1979).

Finally, a positive correlation has been found between somatomedin P (Gluckman and Brinsmead, 1976) or somatomedin C (Underwood et al., 1978) in the umbilical cord blood and the weight of the human baby at birth. However, while somatomedin formation is GH-dependent, CS and perhaps other placental hormones also induce somatomedin C synthesis (Hurley et al., 1977) ; the increment of somatomedin C concentration would be the same for equal doses of GH or CS. Moreover, hCS (human chorionic somatotropin) is positively correlated with the serum level of somatomedin $C$ which binds to fetal tissue receptors (Underwood et al., 1978). These authors conclude that the chorionic somatotropic hormone is essential to fetal growth ; it would initiate the synthesis of somatomedin and use it as a mediator.

Heinrich ef al. (1978) confirm that NSILA (a peptide of the somatomedin family) concentration is positively correlated with the birthweight of newborn infants. 
Contrary to the preceding conclusions, Jost (1977) postulates a more important role for thyroid hormones than for $\mathrm{GH}$ in rat and sheep fetuses. However, encephalectomized rat fetuses with an intact pituitary show slower growth than decapitated ones deprived of GH (Rieutort and Jost, 1976). Girard ef al. (1976) note that plasma GH concentration in 21.5-day fetal rats is lower in larger fetuses and reciprocully. Ponderal growth continues for the first 4 postnatal weeks in newborn hypophysectomized rats (Walker et al., 1952).

Thyroidectomized sheep fetuses with retarded growth have a plasma GH concentration twice that of the controls (Hopkins and Thorburn, 1972). Liggins and Kennedy (1968) reported that a hypophysectomized sheep fetus which continued to grow was smaller than its twin control. Barnes ef al. $(1976,1977)$ also noted that after hypophysectomy the fetus continued to develop and that the lambs survived and grew after birth for $\mathbf{3 0}$ to $\mathbf{4 0}$ days. However, the retarded skeletal growth noted by Hopkins and Thorburn (1972) apparently resembled that of thyroidectomized lambs. This interpretation was confirmed by the data of Thorburn and Hopkins (1973) who reported that thyroxinemia was very low after hypophysectomy.

Owing to its effects on skeletal development, somatomedin may also be involved. In fact, somatomedin $P$ concentration, which does not vary during the last quarter of ovine fetal life, decreases after fetal hypophysectomy : $0.31 \mu \mathrm{g} / \mathrm{ml}$ instead of $0.91 \mu \mathrm{g} / \mathrm{ml}$ in the controls (Robinson et al., 1978). The concentration of fetal somatomedin $C$ in pigs is constant between day 24 and the end of fetal life, showing values of about 25 p. 100 of that of the dam (d'Ercole ef al., 1976).

This possible role of somatomedin appears in the results of Robinson et al. (1976, 1977) who, using the technique of Alexander (1964), induced retarded fetal development by resecting some of the endometrial caruncles in the ewe before pregnancy. The fetuses were hypoglycemic and hypoinsulinic whether or not growth was retarded. Those with retarded growth also had normal plasma oGH concentration, very little prolactin and a significantly lower somatomedin level than the controls (Falconer et al., 1977). Decreasing the placental surface might cause a decline in oCS secretion which would explain the drop in somatomedin content (Robinson et al., 1978).

The relations between thyroid activity and fetal growth have been evidenced by fetal thyroidectomy, since many studies on the ewe have shown the placenta to be impermeable to thyroid hormones (Nathanielsz et al., 1973a; Thorburn and Hopkins, 1973 ; Mellor ef al., 1976).

The fetal sheep thyroid begins to bind iodine from day 50 of fetal life (Fisher et al., 1977). Thyroxinemia is at first low, then augments at 100 days to values higher than the maternal ones; it remains high until day 135 of about a 145-day pregnancy. On the other hand, triiodothyronine, which is detectable just before birth, increases rapidly during the first postnatal days (Nathanielsz ef al., 1973b).

In the bovine fetus during the last trimester of fetal live, plasma thyroxine concentration is clearly higher than in the dam ; fair amounts of triiodothyronine are also found (Strbak ef al., 1976).

Fetal thyroidectomy in sheep caused a drop in thyroxinemia and extended pregnancy ; ponderal growth also slowed down and the appearance of ossification centers was retarded. These effects disappeared after thyroxine treatment (Hopkins and Thorburn, 1972 ; Thorburn, 1974 ; Robinson et al., 1978). The fetuses also had shorter 
legs but the same trunk length as the controls, and died after birth since they could not suckle or stand up and the thermoregulatory system did not function.

These data differ from those obtained on the rabbit (Jost, 1971, 1977) in which fetal thyroidectomy did not prevent fetal growth but increased body fat. The thyroid however begins to differentiate and function late in this species.

To our knowledge, there are no data on the correlations between thyroxinemia or its pattern, and the fetal development of domestic animals.

However, Barlet and Theriez (1979) obtained a positive and significant correlation between plasma triiodothyronine concentration in lambs from birth to postnatal day 7 and their birthweight. On the other hand, the correlation between birthweight and thyroxinemia was only positive when determined 3 days after birth.

Terqui (1978) showed a very strong relation between peripheral blood total estrogen concentration in the ewe at day 110 of pregnancy and in the sow at day 25 and the total weight of the young at birth; maternal estrogen levels would explain the 50 to 60 p. 100 variability in litter weight.

Fetal growth and the total estrogens of maternal plasma would be highly correlated. Maternal effect, expressed by estrogen level at day 110 of pregnancy, would continue to affect growth after birth, since Terqui has evidenced a positive correlation between maternal estrogens and the postnatal growth of lambs up to about 90 days. He obtained parallel results in cattle and goats. A similar correlation between maternal urinary estradiol and the birthweight of newborns would also exist in women.

Trying to analyze the mode of estrogen action. Terqui (1978) proposed some mechanisms. Estrogens would favorize uterine development (Knight et al., 1977), augment blood flow (Caton et al., 1974 ; Barron, 1978) and increase liver weight. Moreover, they would influence mammary gland development, thus explaining the relation between the total plasma estrogens of the pregnant female and the milk production after parturition (Terqui, 1978).

The role of insulin is suggested by some observations on humans and rats. In fact, the children of diabetic mothers often have a higher-than-normal weight may be due to fat accumulation (Cardell, 1953). The fetus of the pregnant diabetic woman is hyperinsulinic ; the abnormally high amount of insulin is not transferred to the fetus, the placenta being considered as impermeable to that hormone. The high level would result from the transfer of maternal glucose to the fetus, hyperglycemia, when it is too high, causing fetal hyperinsulinemia (Jost, 1977).

Girard et al. (1976) studying the rat, note that, contrary to the $\mathrm{GH}$ pattern, fetal plasma insulin level at 21.5 days is higher in bigger fetuses and reciprocally.

Atinmo et al. $(1976 a, b)$ in their studies on the influence of the dietary protein level in the pregnant sow show that from week 13 of fetal life, insulinemia increases more rapidly in the fetus as the dietary protein level of the sow increases. There would thus be a positive correlation between insulinemia and fetal growth rate. Maternal insulinemia is also affected since it rises with the protein level from week 10 of pregnancy *.

* These authors note no influence of the protein composition of the maternal diet on fetal plasma pGH level, which is about 10 times higher than in the sow. It should be remembered that the pregnant sow has no $\mathrm{PCS}$. 
In ruminants, the plasma contains larger amounts of fructose than of glucose, and pancreatic insulin release would be regulated by an increment on glycemia in utero (Shelley, 1973 ; Bassett et al., 1973 ; Alexander et al., 1973) ; there would be less response to an increase of fructosemia (Bassett et al., 1973).

Robinson et al. $(1976,1977)$, studying the effect on fetal growth of uterine cotyledon resection in the pregnant ewe, noted that the fetuses were hypoinsulinic and hypoglycemic whether or not their growth was retarded.

Thus, insulin could not be implicated in the retarded growth observed in the experiments of Robinson et al.

There are few data on the effects of prolactin. It should be recalled that prolactin concentration is low in the fetal sheep with retarded growth (Robinson et al.). These authors even suggested a fetal regulation of somatomedin activity by prolactin since this activity was lower than in the controls. Bala et al. $(1978 a, b)$ reported that prolactin induces the production of somatomedins and increases their activity in the female rat hypophysectomized 60 days after birth. (An article dealing with growth hormone, somatomedins and prolactin during fetal life has just been published. If discusses the secretions and effects of these hormones in the human mother, fetus and newborn (Baumann, 1979).)

Plasma corticosteroid concentration increases in the fetal plasma during the last prenatal days (sheep : Liggins et al., 1973 ; Bassett and Thorburn, 1969 ; cattle : Fairclough ef al., 1975 ; Hoffmann ef al., 1976 : pigs : Fèvre, 1975). These fetal hormones initiate parturition in the mother (Liggins et al., 1973).

2. - Affer birth.

Several aspects of the interrelations between hormonal activity and some growth factors in domestic animals have been studied.

a) Correlations between hormonal concentrations and growth.

These concentrations have been determined in the endocrine glands and in the plasma.

Most research carried out on $\mathrm{GH}$ has shown no correlation between pituitary GH content and animal weight (cattle : Armstrong and Hansel, 1956 ; Hafs ef al., 1971 ; sheep : Charrier, 1973). The ratio : amount of pituitary $\mathrm{GH}$ /body weight is maximum at birth and decreases rather rapidly with the age of the calf (Curl et al., 1968), sheep (Charrier, 1973) or pig (Baird ef al., 1952 ; Baker et al., 1956), but none of these authors could show any correlation between this pattern and growth.

However, they generally agree that the plasma GH levels are high at birth then decrease with age (cattle : Purchas et al., 1970 ; Hafs ef al., 1971 ; Trenkle and Irvin, 1970 ; Joakimsen and Blom, 1976 ; Trenkle and Topel, 1978 ; sheep : Johns, 1974 ; Johns and Bergen, 1976 ; pigs : Chappel and Dunkin, 1975 ; Althen and Gerrits, 1976a ; chicken : Harvey and Scanes, 1978). Thus, plasma GH level in the chicken particularly declines from 10 weeks in females and from 11 weeks in males (Harvey and Scanes, 1978). In cattle, Joakimsen and Blom (1976) report that although plasma GH content tends to decrease with age, it temporary increases in the bull calf between 6 and 8 months, the period when daily live-weight would be maximum.

This plasma concentration would be higher in males than in females (cattle : 
Trenkle and Irvin, 1970 ; Reynaert ef al., 1976 ; sheep : Fowler et al., 1968) ; no difference is found however between male and female pigs (Chappel and Dunkin, 1975). In cattle (Trenkle, 1977 ; Trenkle and Topel, 1978) and sheep (Wallace and Bassett, 1970 ) it is little affected by the plane of nutrition.

Data in the literature do not agree on the correlations between plasma GH content and some growth factors, the results varying with breed, age and sex. In pigs, for example, the correlation with growth rate is positive and significant in males between 3 and 7 weeks, but non-significant in females. On the other hand, after 7 weeks it is negative but non-significant in both sexes (Chappel and Dunkin, 1975).

However, in general the correlation between plasma GH level and growth rate is non-significant or negative and low (bovines : Purchas ef al., 1970 ; Hafs ef al., 1971 ; Trenkle, 1977 ; pigs : Siers and Hazel, 1970).

The correlation with the percentage of carcass adipose deposits is usually negative (cattle (table 1) : Trenkle and Irvin, 1970 ; Trenkle and Topel, 1978 ; pigs : Chappel and Dunkin, 1975) ; however, some authors have found a positive correlation in pigs (Siers and Hazel, 1970 ; Siers and Swiger, 1971).

The correlation between plasma GH and carcass muscle weight is usually positive (table 1) (Trenkle and Irvin, 1970 ; Joakimsen and Blom, 1976 ; Trenkle and Topel, 1978) for cattle, and sometimes negative as in pigs (Siers and Hazel, 1970 ; Siers and Swiger, 1971 ; Chappel and Dunkin, 1975). However the area of a section and the RNA content of the bovine longissimus dorsi on one hand, and the plasma GH level on the other show parallel variation (Trenkle and Irvin, 1970 ; Trenkle and Topel, 1978) (table 1). These data show that a high amount of plasma GH is usually associated with a high muscle/adipose deposit ratio.

TABLE 1

Correlations befween plasma hormone levels and some growth parameters in cattle

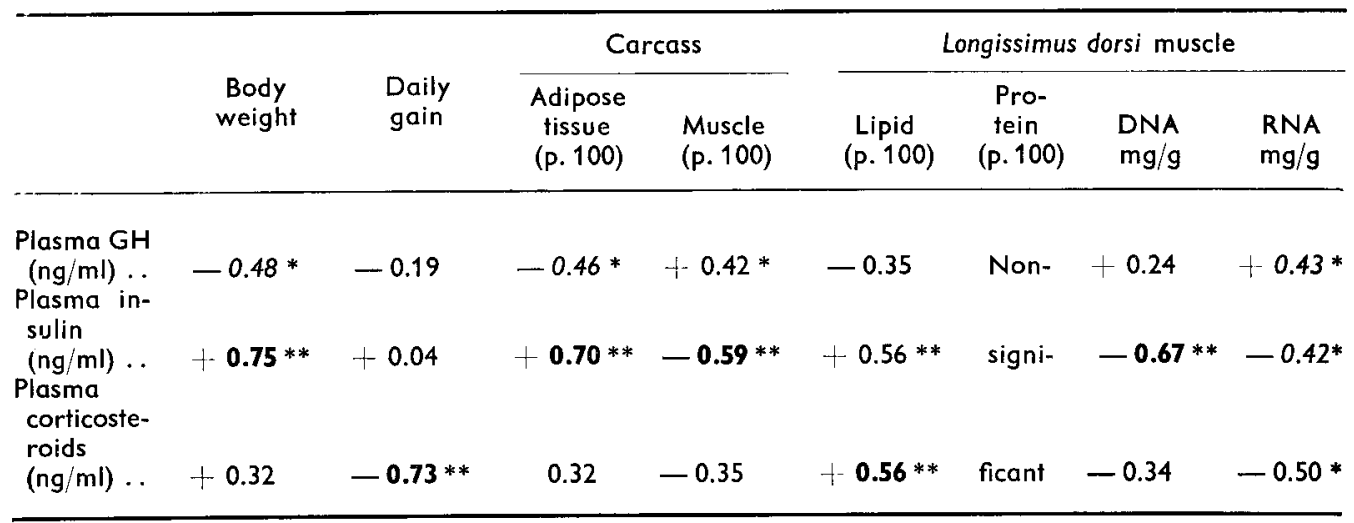

* Significant $(P<0.5)$; ** very significant $(P<0.1)$ (From Trenkle and Topel, 1978).

Data on the interrelations between serum somatomedin level and growth in domestic animals are rare. Lund-Larsen ef al. (1977) obtain a positive correlation between plasma somatomedin A and growth rate or linear growth in cattle ; somato- 
medin level would vary little between 4 and 7 months, and then would increase at about 10 months. Harvey and Scanes (1977) find contrary results on the chicken. They report that the plasma somatomedin $\mathrm{P}$ level in males (assayed on pig costal cartilage) is maximum at about 5 weeks.

In the rabbit, serum somatomedin $A$ level augments from postnatal day 3 , increasing from $0.5 \mu \mathrm{g} / \mathrm{ml}$ at 10 days to $1 \mu \mathrm{g} / \mathrm{ml}$ at 180 days (Charrier, 1978). Between birth and 2 days, the serum inhibits somatomedin $A$ effect ; this point will be discussed later. Hall and Filipsson (1975) studying the child, obtain a high positive correlation between plasma somatomedin $A$ level and growth rate at the same age.

These results show that, in spite of the effects of the GH analyzed previously, the correlations befween plasma concentration and growth are not very clear. However, there usually seems to be a negative correlation with adiposity and a positive one with carcass muscularity.

On the other hand, some authors studying corticosteroids have found that the plasma cortisol level has a high negative correlation with liveweight gain in cattle (Obst, 1974 ; Trenkle and Topel, 1978) (table 1). The latter authors obtained a very significant negative correlation with lipid and RNA contents in the bovine longissimus dorsi. They also observed that cortisolemia increased with age, the increase being aggravated by dietary restriction.

Testosteronemia varies with age in males, particularly in regard to sexual maturation. However, at a given age, no significant correlation is found befween testosteronemia and growth rate in bull calves (Lund-Larsen ef al., 1977). Sitarz ef al. (1977), on the other hand, observed that at a given age, bulls which had the highest growth also had the highest testosteronemia, but these experiments were carried out comparing rations with different protein levels.

Insulinemia would tend to augment with age in the lamb (Johns and Bergen, 1976) and in weaned cattle (Trenkle, 1970 ; Trenkle and Topel, 1978). The results of Young ef al. (1970) and Kosugiyama ef al. (1975) are more complex; they show that diet composition, especially cereal content, affects insulinemia ; this was also reported in the first experiments mentioned.

Trenkle and Topel (1978) show high positive correlations between insulinemia and liveweight, the percentage of carcass adipose deposits and muscle lipids in cattle. The correlations with the percentage of carcass muscle and longissimus dorsi DNA and RNA are high but negative (table 1). The correlations between basic insulinemia and adiposity would not be surprising since the lipogenic and antilipolytic effects of insulin are well known, particularly in humans where obesity is usually associated with high insulinemia. The problem is different in ruminants due to their special metabolism in which lipid is primarily synthesized in the adipose tissue from acetic acid which is the key energetic metabolite in these animals.

Thyroxinemia increases in the first postnatal hours in lambs (Reklewska, 1975) and calves (Kahl et al., 1977) or in the first few postnatal days in pigs (Slebodzinski, 1965). After this initial increment, it decreases; another decline is observed after weaning. In the lamb (Reklewska, 1975), thyroxinemia then reaches levels comparable to those 
of the adult. In the calf, on the other hand, it is elevated after 6 weeks, being 80 p. 100 higher in the adult than at 6 weeks.

The thyroxine/triiodothyronine ratio in the calf is modified, increasing from 27 at birth to 55 at 6 weeks and to 37.5 at 22 weeks (Kahl ef al., 1977). However, interrelations with grouwth are rare.

We wish to compare the previous results with those of Lunn ef al. (1979) on Gambian children whose growth is retarded between 3 months and 3 years of age due to undernourishment, which makes them unresistent to certain diseases (gastroenteritis, malaria, etc.) and affects their growth. These authors tried to determine the effect of unfavorable environmental factors on hormonal balance. They noted that plasma insulin level decreased after birth to stabilize from about 1 year. Plasma GH and cortisol levels augmented, reaching a maximum at about $11 / 2$ years, then declined until 3 years.

They obtained : a positive correlation between insulinemia and ponderal growth rate, especially the rate of height increase ; a negative correlation between cortisolemia and growth rate; a low negative correlation at the significance limit between plasma GH level and growth rate, and a high positive correlation between the insulinemia/cortisolemia ratio and growth rate.

The authors reported similar results on rats fed an energy and/or protein-restricted dief.

They considered that under stress (undernourishment, sickness, etc.) cortisol secretion would increase and that energy restriction would lower insulin release. These two hormones would act on hepatic somatomedin formation under the effect of $\mathrm{GH}$, the insulin being synergic and the cortisol a GH antagonist (Daughaday ef al., 1976).

In closing this section on growth, it is fruifful to try to establish a correlation between these hormonal levels and other functions, as for example, lactation, by comparing high and low potential cows (24 and $10 \mathrm{~kg}$ of milk/day on week 7 of lactation). Hart ef al. (1978) note that high potential animals have a higher plasma GH and a lower insulin content during lactation than low producers. After drying-off, the high producers have the lowest thyroxine level.

TABLE 2

Levels, secretion and metabolic clearance rates of plasma GH in cattle (Mean values in limited and full-fed cattle of different sizes and genotypes)

\begin{tabular}{cccc}
\hline $\begin{array}{c}\text { Slaughter weight } \\
\text { (and no. of animals) }\end{array}$ & $\begin{array}{c}\text { Plasma level } \\
(\mathrm{ng} / \mathrm{ml})\end{array}$ & $\begin{array}{c}\text { Secretion } \\
(\mu \mathrm{g} / \mathrm{h})\end{array}$ & $\begin{array}{c}\text { Metabolic clea- } \\
\text { rance rate } \\
(\mathrm{l} / \mathrm{h})\end{array}$ \\
\hline & & & \\
$113 \mathrm{~kg}(2) \ldots \ldots \ldots \ldots$ & 8.9 & 188 & 20.6 \\
$363 \mathrm{~kg}(4) \ldots \ldots \ldots \ldots$ & 5.5 & 201 & 36.8 \\
$505 \mathrm{~kg}(4) \ldots \ldots \ldots$ & 4.5 & 239 & 52 \\
\hline
\end{tabular}

(From Trenkle and Topel, 1978.) 
b) Correlations between the kinetics of hormone metabolism and growth.

Plasma concentrations are the result of fixed factors : secretion rate (hormone release into plasma by the gland synthesizing the hormone) and metabolic clearance rate.

These factors have been siudied on sheep (Trenkle, 1976) and cattle (Trenkle and Topel, 1978). The latter authors showed (table 2) that these two factors increased for $\mathrm{GH}$ with liveweight and age and were unaffected by the plane of nutrition or the breed. Althen and Gerrits (1976b) obtained similar results in pigs.

On the other hand, these factors, corrected to the kilogram of liveweight, decreased with age. They had a negative correlation with liveweight as well as with the amount of carcass fat and longissimus dorsi lipids, and a positive correlation with the percentage of carcass muscle and amount of longissimus dorsi RNA. On the contrary, correlation with weight gain was not significant. These correlations are thus similar to those previously mentioned in relafion to plasma concentration (table 3 ).

TABLE 3

Correlations of endocrine measurements with body weight, growth rate and body composition of cattle

\begin{tabular}{|c|c|c|c|c|c|c|c|c|}
\hline \multirow[b]{2}{*}{ Parameters } & \multirow[b]{2}{*}{$\begin{array}{c}\text { Body } \\
\text { weight }\end{array}$} & \multirow[b]{2}{*}{$\begin{array}{l}\text { Daily } \\
\text { gain }\end{array}$} & \multicolumn{2}{|c|}{ Carcass } & \multicolumn{4}{|c|}{ Longissimus dorsi muscle } \\
\hline & & & $\begin{array}{l}\text { adipose } \\
\text { tissue } \\
\text { (p. 100) }\end{array}$ & $\begin{array}{l}\text { Muscle } \\
\text { (p. 100) }\end{array}$ & $\begin{array}{l}\text { Lipid } \\
\text { (p. 100) }\end{array}$ & $\begin{array}{l}\text { Pro- } \\
\text { tein } \\
\text { (p. 100) }\end{array}$ & $\begin{array}{l}\text { DNA } \\
\mathrm{mg} / \mathrm{g}\end{array}$ & $\begin{array}{l}\text { RNA } \\
\mathrm{mg} / \mathrm{g}\end{array}$ \\
\hline $\begin{array}{l}\text { Plasma GH } \\
\text { (ng/ml) } \ldots . . . \\
\text { Metabolic clea- } \\
\text { rance rate }\end{array}$ & $-0.48^{*}$ & -0.19 & $-0.46 *$ & $+0.42 *$ & -0.35 & -0.24 & $+0.43 *$ & $+0.24 *$ \\
\hline $\begin{array}{l}(1 / \mathrm{h} / \mathrm{kg}) \\
\text { Secretion } \\
\begin{array}{l}\text { per } \mathrm{kg} \\
(\mu \mathrm{g} / \mathrm{h} / \mathrm{kg})\end{array} \\
\end{array}$ & $\begin{array}{l}-0.77^{* *} \\
-0.57^{* *}\end{array}$ & +0.14 & $\begin{array}{l}-0.53^{* *} \\
-0.55^{* *}\end{array}$ & +0.44 & $-0.41 *$ & -0.16 & $\begin{array}{l}+0.41 * \\
+0.45 *\end{array}$ & $+0.55 * *$ \\
\hline
\end{tabular}

* $\mathrm{P}<0.5 ; * * \mathrm{P}<0.1$ (From Trenkle and Topel, 1978).

c) Mode of action of some hormonal treatments.

The mode of action of two hormonal treatments has been studied; one treatment used sex steroids, the other TRH (thyrotropin releasing hormone).

As mentioned earlier, some sex steroids (diethylstibestrol, melengestrol acetate, for example) have a growth effect which is marked in castrated male cattle, less evident in females, and weak in intact males. In an attempt to determine the mode of action of these steroids, Trenkle (1970). Purchas ef al. (1971) and Hafs ef al. (1971) studying cattle, reported their action on the concentration, secretion and metabolic clearance of different hormones to determine if the steroids had direct or indirect effects. Melengestrol acetate tended to decrease plasma GH and cortisol levels in sheep (Hafs ef al., 1971), confirming the correlations already mentioned, especially the negative one between plasma corticosteroid level and liveweight gain. 
The diethylstibestrol treatment, which augmented liveweight gain by 12 p. 100 in bull calves, caused plasma GH concentration to rise up to day 50 of treatment (Trenkle, 1970). After 50 days, the level tended to decline but remained higher than that of the controls. The effects on insulinemia were low. Trenkle (1969) studying diethylstibestrol intake in lambs, reported increased insulinemia with no large variations of basal glycemia. In pigs, Bidner ef al. (1973) obtained a significant increment of serum GH concentration, especially in castrates.

Finally, in cockerels, in which testosterone slows down growth, this hormone induces an earlier decrease of the plasma GH level than in the controls (Harvey and Scanes, 1978).

Other hormonal trials using chronic treatment have been carried out with TRH which increased thyroid and prolactin hormone secretions ; Davis ef al. $(1976,1977)$ working on lambs, McGuffey ef al. (1977) on calves, and Davis et al. (1977) on heifers reported a higher growth rate in treated animals. In heifers, this treatment enhanced the prolactin level more than the GH level (Davis et al., 1977). In calves, an increase of insulinemia was observed after each TRH injection (McGuffey et al., 1977). On the other hand, Convey (1973) showed that when the lactating cow was perfused with TRH, serum $\mathrm{GH}$, prolactin and thyroxine levels increased concomitantly with milk producJion.

d) Effect of selection.

Another way of determining hormone-growth intercorrelations is to select for certain growth-releated factors, and thus modify hormonal balances.

Most of this work has been carried out on pigs. Althen and Gerrits $(1976 a, b)$ selected strains of the Duroc and Yorkshire breeds for backfat thickness which varied from 1 to 2.7 ( 28.1 to $75.1 \mathrm{~mm}$ ) when the animals were slaughtered at a liveweight o $95 \mathrm{~kg}$ at about 30 weeks of age. These sirains were compared to a control strain which had not been selected for backfat thickness. When weaned at about 8 weeks old, the fat animals of both breeds had the lowest serum GH content; the differences still persisted at slaughter although they were less (table 4).

\section{TABLE 4}

Serum GH levels at birth and weaning in Duroc and Yorkshire pigs selected for backfat thickness

\begin{tabular}{llccc}
\hline \multirow{2}{*}{ Breed } & Stage & \multicolumn{3}{c}{ GH serum levels $(\mathrm{ng} / \mathrm{ml})$ of : } \\
\cline { 3 - 5 } Duroc & Birth $\ldots \ldots \ldots$ & $\begin{array}{c}\text { thick backfat } \\
\text { animals }\end{array}$ & controls & $\begin{array}{c}\text { thin backfat } \\
\text { animals }\end{array}$ \\
\hline \multirow{2}{*}{ Yorkshire } & Weaning $\ldots \ldots$ & 34.6 & 20.3 & 46.1 \\
& Birth ........ & 2.9 & 5.9 & 5.3 \\
\hline
\end{tabular}

(From Althen and Gerrits, 1976.) 
In a second experiment, the same authors tried to determine the influence of selection on the rates of $\mathrm{GH}$ secretion and metabolic clearance in Duroc pigs, but they could find no differences between fat, lean and control strains.

Lund-Larsen and Bakke (1975) selected two swine strains differing in growth rate, carcass length and fat thickness. The lean animals grew faster, had a longer carcass than the fat ones, and were characterized by the highest serum GH and somatomedin levels. Moreover, these pigs had a higher triiodothyronine level. The thyroxine level was also higher, but only at $20 \mathrm{~kg}$ of liveweight (Bakke and Treit. 1977).

Wood et al. (1977) compared the lipid mobilization aptitude of Pietrain and LargeWhite pigs ; the Pietrain had a leaner carcass. After a meal or during fasting, they showed lower glycemia and insulinemia with higher plasma fatty acid concentrations. Moreover, these pigs were less sensitive to insulin antilipolytic action and more sensitive to the lipolytic effect of norepinephrine. These authors showed a correlation between a marked ability to mobilize lipids and a leaner carcass. The leanness of the Pietrain pigs would be due to limited fat deposit rather than to increased lean mass (Lister, 1978). Lean pigs also have a high percentage of muscle, are very sensitive to stress and produce exudative meat more often than fatter animals.

Highly muscular cattle are also sensitive to stress and have a large number of white $\alpha W$ muscle fibers (Ashmore, 1974).

However, some authors consider that the injection of glucorticoids may cause myopathy (Vignos and Greene, 1973 ; Mayer and Rosen, 1977) by acting on the white, rapid-contraction, $\alpha W$ fibers in the rabbit (Smith, 1964 ; Mayer and Rosen, 1977).

\section{III. - Experimental limitations}

Some of the following limitations inherent in the studies mentioned may be the. cause of the contradictory or insufficient results oblained :

\section{1. - Fluctuations of hormonal levels.}

Many authors have not taken into account that the fluctuations of hormonal levels. may result in a faulty interpretation of their correlation with growth.

Plasma GH concentrations have been mostly studied in humans and rats. Outjes and Ney (1972) have shown a diurnal rhythmicity in humans who evidence a minimal concentration in the morning before waking and a secrefion peak at the beginning of deep sleep. Moreover, physical exercise, stress or eating a protein-rich meal, for example, causes a temporary increase of plasma content. Besides this diurnal rhythmicity, the plasma level of the rat is pulsatile, showing secretion peaks about every 3.9 hrs (Tannenbaum and Martin, 1976). Several authors have found this same type of rhythmicity in the plasma GH concentration in cattle ; they mention that these patterns show 1 to 3 peaks over à 5.5-hr period (Trenkle, 1977), or a double peak every 3.5 to $5 \mathrm{hrs}$ (Driver and Forbes, 1978). However, these fluctuations are less marked than in humans or rats (Wagner and Oxenreider, 1972 ; Trenkle, 1977 ; Trenkle and Topel, 1978).

In ruminants, the GH concentration varies with a certain number of factors, and after a meal a different pattern is obtained in the suckling young than in adults (Bassett, 1974a, b). In lambs, it decreases slightly after suckling, then increases, clearly 
showing a maximum $30 \mathrm{mn}$ after milk intake. In adult sheep, on the other hand, a meal is followed by a rapid decline of plasma GH which, instead of increasing as in the lamb, then remains low for about 4 hrs before rising to reach a level similar to the preprandial value. The minimum plasma $\mathrm{GH}$ concentration in the adult would be concomitant with a high volatile fatty acid concentration, low in free fatty acids (FFA). Perfusion of volatile fatty acids, hypoglycemia, fasting and stress would have relatively little effect on ruminant plasma GH content, which is more stable than in human or rats (Wallace and Bassett, 1970 ; Wagner et al., 1970 ; McAtee and Trenkle, 1971 ; Reynaert ef al., 1976). On the other hand, a drop in glycemia, fasting and stress would stimulate GH secretion in pigs (Machlin ef al., 1968).

Other hormones, such as corticosteroids, show similar fluctuations.

It is thus evident that endocrine gland or blood sampling affects the hormonal concentrations recorded.

\section{2. - Paucity of data on growth peptides.}

Somatomedins, especially somatomedins $A, C$ and $P$, are considered as active $\mathrm{GH}$ mediators. However, they are not the only peptides implicated in growth; some of the most important ones are various $\mathrm{GH}$-dependent somatomedins which are differentiated by the biological material used for their assay (Van Wyk et al., 1973, 1974). Somatomedin $A$ is assayed by radioactive sulfate $\left({ }^{35} \mathrm{~S}\right)$ incorporation in vitro into the proteoglycans of chick embryo pelvis (Hall, 1970) ;

somatomedin $B$ by tritiated thymidine incorporation in vitro into human glial cells (Uthne, 1973) ;

somatomedin $C$ by radioactive sulfate or tritiated thymidine incorporation into hypophysectomized rat costal cartilage (Van Wyk et al., 1973) ; and

somatomedin $P$ by radioactive sulfate incorporation in vitro into pig costal cartilage (Van Den Brande and Van Buul, 1978).

These somatomedins, which have a molecular weight of 5000 to 7000 , are characterized by (i) their GH-dependence, (ii) their somatotropic effects, particularly on the skeleton : plasma sulfation factor (PSF) (Salmon and Daughaday, 1957 ; Daughaday et al., 1959), and (iii) their insulin-like effects on adipose, muscle and hepatic tissues (even in the presence of antibodies raised against insulin).

At present, four somatomedins have been found : somatomedins $A_{1}$ and $A_{2}$ isolated by Uthne, C by Van Wyk and P by Van Den Brande. Somatomedin B is no longer considered as a somatomedin because it has a weak action on cartilage sulfate incorporation (Fryklund ef al., 1976).

Besides these somatomedins are other growth peptides which all have the same characteristics as those mentioned above, including GH-dependence. Some of the main ones are the NSILA's (non-suppressible insulin-like activity-soluble). In fact, in some situations, such as fasting in humans, plasma immunoreactive insulin (IRI) of pancreatic origin only accounts for about 10 p. 100 of the bioactive insulin or ILA (insulin-like activity). The major part of ILA is not suppressed by insulin antibodies, and thus corresponds to the NSILA's whose active part can be extracted with ethanol acid ; their physiology has been compared by numerous authors (Megyesi ef al., 1977). Recently, 
another peptide, or purified ILA, has been isolated by Posner and Guyda (1976) and studied by Corvol et al. (1978).

The NSILA's are composed of two factors, IGF I and IGF II (insulin growth factor) which have been purified by Rinderknecht and Humbel $(1978 a, b)$. Their primary structure is similar to that of proinsulin (Zapf ef al., 1978a, b).

Besides the NSILA's, MSA (multiplication-stimulating activity), a necessary serum factor in the multiplication of most animal cells in culture (Nissley and Rechler, 1978), was isolated by Pierson and Temin in 1972. This factor stimulates sulfate incorporation into rabbit costal chondrocytes in culture.

Aside from this family of peptides, other growth peptides have been found whose $\mathrm{GH}$ dependence is doubtful or very unlikely ;

NGF (nerve growth factor), extracted in 1960 by Cohen from the sub-maxillary glands of male rats, is composed of several sub-units, among which $\beta 1$ acts on the nerve cells. Its formation in the sub-maxillaries would be testosterone-dependent (Berger and Shooter, 1978 ; Thoenen ef al., 1978) ;

EGF (epidermal growth factor), isolated in 1962 by Cohen, is of unknown structure and has a mitogenic effect on epidermal and granulosa cells, for example (Gospodarowicz et al., 1978 ; Carpenter and Cohen, 1978) ;

FGF (fibroblast growth factor), isolated by Gospodarowicz, stimulates the mitoses of chondrocytes and hepatocytes, for example (Gospodarowicz ef al., 1978) ;

MGF (myoblast growth factor) induces myoblast proliferation and fusion (Nicholson, 1976 : Gospodarowicz et al., 1978) ;

Erythropoietin is at least partially under GH control but does not act on the skeleton (Van Wyk ef al., 1973) ;

Serum factors $S_{1}, S_{2}$ and $S F_{I I}$ have been reported by Frank et al. (1975) and Dieter ef al. (1978).

Somatomedins A and IGF I on one hand, and MSA and IGF II on the other, seem to have similar structure, receptor binding and immunology (Zapf et al., 1978), but only the determination of somatomedin primary structure can furnish definitive proof of these suppositions.

The study of these GH-dependent peptides is complicated by the existence of vector proteins and inhibitory substances. In fact, the peptides bind to serum proteins, but it is not known if each peptide has its own vector protein, or if only one or a few of them exist (Zapf et al., 1978). For example, somatomedins $A_{1}$ and $A_{2}$, IFG I, IGF II and MSA compete for a partially purified protein binding. The vector protein binding of these peptides evidently interferes with their assay and action (Zapf ef al., 1978).

Moreover, there may be one or more serum peptide inhibitors. Charrier (1978) showed that young rabbit serum contained one or more substances inhibiting somatomedin A from 2 days before birth to 2 days after. These inhibitory substances would also be found in the serum of children or rats suffering from denutrition where " somatomedin " activity is low or non-existent in spite of high plasma GH content (Van Den Brande and Du Caju, 1973 ; Salmon, 1975).

It is therefore understandable that the almost total lack of data on these peptides in domestic animals calls for prudence when interpreting hormone-growth interrelations. 
3. - Limitations due to possibly deficient assay methods.

The assay methods used seem well founded (biological assay, competitive binding, radioimmunology, for example), but the results are sometimes difficult to interpret, as in the case of insulin before the insulin-like serum factors were known.

This would also be the case of $\mathrm{GH}$ which is radioimmunologically assayed in the plasma because its concentrations are of the order of some nanograms per $\mathrm{ml}$, and hence impossible to measure by the biological tibia test. However, according to Ellis and Grindeland (1973) and Ellis et al. (1978), the results of these two methods of measurement are sometimes very divergent, ranging from 1 to 5 to 1 to 200 (table 5). These differences are found whether the $\mathrm{GH}$ is assayed in the plasma or the pituitary, and they cannot be explained by the presence of somatomedins, NSILA's or GH-dependent factors. According to Ellis et al. (1978), they would result from the presence of large molecules having biological, but not immunological, GH-like activity. The molecules would have a molecular weight of 60000 to 80000 and would form in the pituitary as well as in the plasma after $\mathrm{GH}$ injection; they would not induce somatomedin $\mathrm{C}$ formation.

TABLE 5

Comparison of plasma GH levels in humans and rats as measured by radioimmunoassay (RIA) or the tibia test

\begin{tabular}{|c|c|c|c|}
\hline & \multicolumn{2}{|c|}{$\begin{array}{l}\text { Plasma GH concentration } \\
\qquad(\mathrm{ng} / \mathrm{ml})\end{array}$} & \multirow[t]{2}{*}{$\begin{array}{l}\text { Ratio tibia test } \\
\text { RIA concent. }\end{array}$} \\
\hline & RIA & Tibia test & \\
\hline $\begin{array}{l}\text { Human plasma pool } \ldots \ldots \ldots \ldots \ldots \\
\text { Acromegalic plasma } \ldots \ldots \ldots \ldots \ldots \\
\text { Plasma pool of } 450 \mathrm{~g} \text { rats } \ldots \ldots \ldots\end{array}$ & $\begin{array}{l}1.5 \\
40 \\
10.5\end{array}$ & $\begin{array}{r}304 \\
1090 \\
494\end{array}$ & $\begin{array}{r}202 \\
27 \\
47\end{array}$ \\
\hline
\end{tabular}

(From Ellis and Grindeland, 1973 and Ellis et al., 1978.)

4. - Correlations between hormones involved in growth and other hormones, and the biological material used.

In addition to the hormones already discussed, others of the digestive tract act on metabolisms and thus on growth.

Somatostatin, a hypothalamic hormone inhibiting $\mathrm{GH}$ release, was demonstrated in the pancreas and the mucous membranes of the pylorus and the duodenum by Dubois (1975). Besides inhibiting pituitary $\mathrm{GH}$ release, this hormone also prevents pancreatic insulin and glucagon secretion (Guillemin, 1978).

The main gastrointestinal hormones can be divided into two large families which have an analogous structure and inferact antagonistically (Track, 1977 ; Grossman, 1977 ; Johnson, 1977 ; Brown and Otte, 1978). The family of gastric and duodenal gastrins also includes cholecystokinin and motilin. Enteroglucagon, GIP (gastric inhibitory polypeptide) and VIP (vasoactive intestinal polypeptide) are found in the secretin 
family. Aside from their effects on digestive tube secretion or motricity, all these hormones would stimulate secretion of insulin, thus interfering with insulin-dependent metabolisms.

Finally, studies on the effects of hormones on tissues have been carried out too often on rat epididymal tissue or on muscles such as the bulbocavernosus or levator ani whose development in the rat constitutes a secondary sex character, while the various skeletal muscles and adipose tissues do not necessarily respond in the same way to hormones.

5 e Réunion du groupe Développement I.N.R.A., Clermont-Ferrand/Theix, 17-18 mai 1979.

Résumé. Parmi les nombreux facteurs qui agissent sur la croissance fœtale et postnatale, les facteurs hormonaux sont envisagés.

Dans une première partie, les effets généraux des hormones sur la croissance des animaux domestiques sont étudiés avec notamment, le rôle de l'hypophyse et des hormones hypophysaires (hormone de croissance, prolactine, ACTH). L'action des somatomédines est considérée dans ce cadre. Les effets de la thyroïde et des hormones thyroïdiennes, du cortex surrénalien et des corticostéroïdes, des gonades et des stéroïdes sexuels, de l'insuline, sont abordés.

Dans une deuxième partie, le problème des équilibres hormonaux et de la croissance fait l'objet d'une analyse au cours de la vie fœitale et après la naissance.

La complémentarité pendant la vie fœilale des « activités croissance » de l'hormone de croissance $(\mathrm{GH})$ et de l'hormone placentaire somatotrope ou lactogène (CS ou $P L$ ) est soulignée. Les relations entre ces hormones, les somatomédines et la croissance fœetale sont précisées ; les hormones thyroïdiennes, les œstrogènes pourraient aussi avoir un rôle, ainsi que l'insuline dans le développement du fœetus.

Après la naissance on note des liaisons plus ou moins strictes entre les concentrations plasmatiques hormonales et la croissance. Ces concentrations dépendent des paramètres cinétiques du métabolisme des hormones dont les rapports avec la croissance sont étudiés. Le mode d'action de quelques traitements hormonaux et l'effet de la sélection sur certains équilibres hormonaux sont également signalés.

Dans une troisième partie, une étude critique permet d'entrevoir les limites des investi. gations sur l'endocrinologie de la croissance. Sont notamment évoqués le problème des fluctuations des niveaux hormonaux en relation avec l'état nutritionnel, le stress, le moment du nycthémère ainsi que l'insuffisance des connaissances sur les peptides de croissance et les limites des méthodes de dosages.

\section{References}

ALEXANDER D. P., BRITTON H. G., COHEN N. M., NIXON D. A., PARKER R. A., 1973. Insulin secretion in the fetal and neonatal sheep. Biol. Neonate, 22, 99-118.

ALEXANDER D. P., BRITTON H. G., FORSLING M. L., NIXON D. A., RATCLIFFE J. G., 1974. tary and plasma concentrations of adrenocorticotrophin, growth hormone, vasopressin and ocytocin in fetal and maternal sheep during the latter half of gestation and the response to haemorrhage. Biol. Neonate, 24, 206-219.

ALEXANDER G., 1964. Studies on the placenta of the sheep (Ovis aries L.) : effect of surgical reduction in the number of caruncles. J. Reprod. Ferf., 7, 307.

ALTHEN T. G., GERRITS R. J., 1976a. Pituitary and serum growth hormone levels in Duroc and Yorshire swine genetically selected for high and low backfat. J. Anim. Sci., 42, 1490-1497.

ALTHEN T. G., GERRITS R. J., 1976b. Metabolic clearance and secretion rates of porcine growth hormone in genetically lean and obese swine. Endocrinology, 99, 511-515.

ARMSTRONG D. T., HANSEL W., 1956. The effect of age and plane of nutrition on growth hormone 
and thyrotropic hormone content of pituitary glands of Holstein heifers. J. Anim. Sci., 15, 640649.

ATINMO T., BALDIJAO C., POND W. G., BARNES R. H., 1976a. Decreased dietary protein of energy intake and plasma growth hormone levels of the pregnant pig, its fetuses and developing progeny. J. Nutr., 106, 940-946.

ATINMO T., BALDIJAO C., WILSON G. P., BARNES R. H., 1976b. Maternal protein malnutrition during gestation alone and its effects on plasma insulin levels of the pregnant pig, its fetuses and the developin offspring. J. Nutr., 106, 1647-1653.

ASHMORE C. R., 1974. Phenotypic expression of muscle fiber types and some implications to meat quality. J. Anim. Sci., 38, 1158-1164.

BAIRD D. M., NALBANDOV A. V., NORTON H. W., 1952. Some physiological causes of genetically different rates of growth in swine. J. Anim. Sci., 11, 292.

BAKER B., HOLLANBECK R., NORTON H. W., NALBANDOV A. V., 1956. Growth hormone content of swine pituitaries in relation to growth rate and age. J. Anim. Sci., 15, 407-417.

BAKKE H., TVEIT B., 1977. Serum levels of thyroid hormones in lines of pigs selected for rate of gain and thickness of backfat. Acta agric. scand., 27, 41-44.

BALA R. M., BOHNET H. G., CARTER J. N., FRIESEN H. G., 1978a. Effect of ovine prolactin on serum somatomedin bioactivity in hypophysectomized female rats. Can. J. Physiol. Pharmacol., 56, 984-987.

BALA R. M., BOHNET H. G., CARTER J. N., FRIESEN H. G., 1978. Effect of ovine prolactin on serum somatomedin bioactivity in hypophysectomized female rats. Con. J. Physiol. Pharmacol., 56, 984-987.

BARLET J. P., THERIEZ C., 1979. Communication personnelle.

BARNES R. J., COMLINE R. S., SILVER M., 1976. The effects of adrenalectomy and hypophysectomy in the foetal lamb. J. Physiol. London, 254, 15P-16P.

BARNES R. J., COMLINE R. S., SILVER M., 1977. The effects of bilateral adrenalectomy or hypophysectomy of the foetal lamb in utero. J. Physiol. London, 264, 429-447.

BARRON D. H., 1978. Communication personnelle.

BASSETT J. M., 1968. The relation of fat and protein catabolic actions of cortisol to glycose homeostasis in fasting sheep. Mefabolism, 17, 644-652.

BASSETT J. M., 1974a. Early changes in plasma insulin and growth hormone levels after feeding in lambs and adult sheep. Aust. J. biol. Sci., 27, 157-166.

BASSETT J. M., 1974b. Diurnal patterns of plasma insulin growth hormone corticosteroid and metabolite concentrations in fed and fasted sheep. Aust. J. biol. Sci., 27, 167-181.

BASSETT J. M., MADILL D., 1974. The influence of maternal nutrition on plasma hormone and metabolite concentrations of foetal lambs. J. Endocr., 61, 465-477.

BASSETT J. M., MADILL D., NICOL D. H., THORBURN G. D., 1973. Further studies on the regulation of insulin release in foetal and post-natal lambs : the role of glucose as a physiological regulator of insulin release in utero, 351-359. In BARCROFT (Sir J.). Foefal and neonatal physiology. Cambridge Univ. Press.

BASSETT J. M., THORBURN G. D., 1969. Foetal plasma corticosteroids and initiation of parturition in sheep. J. Endocr., 44, 285-286.

BASSETT J. M., THORBURN G. D., WALLACE A. L. C., 1970. The plasma growth hormone concentration of the foetal lamb. J. Endocr., 48, 251-263.

BASSETT J. M., WALLACE A. L. C., 1967. Influence of cortisol on plasma insulin in the sheep. Diabetes, 16, 566-571.

BATES R. W., MILKOVIC S., GARRISON M. M., 1964. Effects of prolactin, growth hormone and ACTH alone and in combination, upon organ weights and adrenal function in normal rats. Endocrinology, 74, 714-723.

BAUMANN G., 1979. Growth hormone, somatomedin and prolactin in pregnancy : their secretion and effects in mother, fetus and newborn Pediat. adolesc. Endocr., 5, 17-35.

BERANGER C., MALTERRE C., 1968. Influence d'un stéroïde triénique à activité anabolisante sur l'engraissement des vaches taries. C. R. Soc. Biol., 162, 1157-1164.

BERGER E. A., SHOOTER E. M., 1978. Nerve growth factor : studies on the localization, regulation and mechanism of its biosynthesis, 83-99. In PAPACONSTANTINOU J., RUTTER W. J., Molecular control of proliferation and differentiation. Acad. Press, New York. 
BIDNER T. D., MERKEL R. A., HAFS H. D., SWANSON L. V., MILLER E. R., 1973. Serum growth hormone levels of pigs fed diethylstilbestrol plus methyltestosterone between 23 and 90 kilograms. J. Anim. Sci., 36, 337-342.

BLOSS R. E., NORTHAM J. I., SMITH L. W., ZIMBELMAN R. G., 1966. Effects of oral melengestrol acelate on the performance of feedlot cattle. J. Anim. Sci., 25, 1048-1053.

BROWN J. C., OTTE S. C., 1978. Gastrointestinal hormones and the control of insulin secretion. Diabetes, 27, 782-789.

BURGESS T. D., LAMMING G. E., 1960. The effect of hormones on growth rate and carcass quality of fattening lambs and hoggets. Anim. Prod., 2, 83-92.

CARDELL B. S., 1953. The infants of diabetic mothers. A morphological study. J. Obstet. Gynaec, Br. Commonw., 80, 834.

CARPENTER G., COHEN S., 1968. Biological and molecular studies of the mitogenic effects of human epidermal growth factor, 13-31. In PAPACONSTANTINOU J., RUTTER W. J., Molecular control of proliferation and differentiation. Acad. Press, New York.

CARROLL F. D., POWERS S. B., CLEGG M. T., 1963. Effect of cortisone acetate on steers. J. Anim. Sci., 22, 1009-1011.

CATON D., ABRAMS R. M., LACKORE L., JAMES G., BARRON G. H., 1974. Effect of exogenous progesterone on the rates of uterine blood flow and oxygen consumption of sheep in early pregnancy. Q. J. exp. Physiol., 59, 233-239.

CHAPPEL R. J., DUNKIN A. C., 1975. Relation of concentration of growth hormone in blood plasma to growth rate and carcass characteristics in the pig. Anim. Prod., 20, 51-61.

CHARRIER J., 1973. Evolution fœtale et postnatale du contenu en hormone de croissance de l'hypophyse ovine. Ann. Biol. anim. Bioch. Biophys., 13, 155-163.

CHARRIER J., 1978. Age dependent variations of somatomedin-A activity in the rabbit. Ann. Biol. anim. Bioch. Biophys., 18, 33-43.

CLARK J. D., DYER I. A., TEMPLETON J., GALGAN M. W., 1963. Effects of cortisone on ruminant performance. I. Anim. Sci., 22, 463-465.

CLAUSER H., 1979. Communication personnelle.

COHEN S., 1960. Proc. nat. Acad. Sci. USA, 46, 302-311. Cité par BERGER E. A. et SHOOTER E. M, 1978.

COHEN S., 1962. J. biol. Chem., 237, 1555-1562. Cité par CARPENTER G., COHEN S., 1978.

CONVEY E. M., 1973. Neuroendocrine relationships in farm animals : A review. J. Anim. Sci., 37, 745-757.

CORDESSE R., 1979. Communication personnelle.

CORVOL M.-T., DUMONTIER M.-F., RAPPAPORT R., GUYDA H., POSNER B. I., 1978. The effect of a slightly acidic somatomedin peptide (ILAs) on the sulphation of proteoglycans from articular and growth plate chondrocytes in culture. Acta endocr. Copenh., 79, 263-275.

CURL S. E., FENNELL M. A., ZINN D. W., ALBIN R. C., 1968. Growth and development of the bovine as related to certain endocrine factors. J. Anim. Sci., 27, 1011-1014.

DAUGHADAY W. H., HALL K., RABEN M. S., SALMON W. D., VAN DEN BRANDE J. L., VAN WYK J. J., 1972. Somatomedin : proposed designation for sulphation factor. Nature, 235, 107.

DAUGHADAY W. H., HERINGTON A. C., PHILLIPS L. S., 1975. The regulation of growth by endocrines. Ann. Rev. Physiol., 37, 211-244.

DAUGHADAY W. H., PHILLIPS L. S., MUELLER M. C., 1976. The effects of insulin and growth hormone on the release of somatomedin by the isolated rat liver. Endocrinology, 98, 1214-1219.

DAUGHADAY W. H., SALMON W. D., ALEXANDER F., 1959. Sulfation factor activity of sera from patients with pituitary disorders. J. clin. Endocr. Mefab., 19, 743-758.

DAVIES J. I., 1973. Drugs affecting free fatty acid release, 158-195. In DIKSTEIN S., Fundamental of cell pharmacology. Thomas, Springfield (IIlinois).

DAVIS S. L., ANFINSON M. S., KLINDT J., OHLSON D. L., 1977. Influence of prostaglandins and thyrotropin releasing hormone $(\mathrm{TRH})$ on hormone secretion and growth in wether lambs. Prostaglandins, 13, 1209-1219.

DAVIS S. L., HILL K. M., OHLSON D. L., JACOBS J. A., 1976. Influence of chronic thyrotropinreleasing hormone injections on secretion of prolactin, thyrotropin and growth hormone and on growth rate in wether lambs. J. Anim. Sci., 42, 1244-1250.

DAVIS S. L., SASSER R. G., THACKER D. L., ROSS R. H., 1977. Growth rate and secretion of pituitary 
hormones in relation to age and chronic treatment with thyrotropin-releasing hormone in prepubertal dairy heifers. Endocrinology 100,1394-1402.

D'ERCOLE A. J., FOUSHEE D. B., UNDERWOOD L. E., 1976. Somatomedin-C receptor ontogeny and levels in porcine fetal and human cord serum. J. clin. Endocr. Metab., 43, 1069-1077.

DESBALS B., 1967. Rôles respectifs des hormones surrénaliennes ef hypophysaires dans le déterminisme des troubles entrainés par la surrénalectomie chez le lapin. Effets extrasurrénaliens de la corticotropine. Th. Dr. Sci. Toulouse. 201 pp.

DIETER P., RISTOW H. J., RUPNIAK H. T., MESSMER T. O., 1978. Growth control by serum factors and hormones in mammalian cells in culture, 65-79. In PAPACONSTANTINOU J., RUTTER W. J., Molecular control of proliferation and differentiation. Acad. Press, New York.

DJIANE J., KANN G., 1975. Mise en évidence de l'activité lactogène et mesure dans le sérum de l'activité prolactinique du placenta chez la brebis au cours de la gestation. C. R. Acad. Sci. Paris, Sér. D, 280, 2785-2788.

DRIVER P. M., BROWN W. B., SCANES C. G., FORBES J. M., 1976. Serum growth hormone levels in growing lambs at two daylengths and two levels of feeding. J. Endocr., 69, 44P-45P.

DRIVER P. M., FORBES J. M., 1978. Plasma growth hormone and spontaneous meals in sheep. Proc. Nutr. Soc., 37, $100 \mathrm{~A}$.

DRIVER P. M., EL SHAHAT A., BOAZ T. G., FORBES J. M., SCANES C. G., 1977. Increase in serum prolactin in sheep associated with long daylength and feeding od libitum. J. Endocr., 72, 46P.

DUBOIS M. P., 1971. Mise en évidence par immuno-fluorescence des cellules somatotropes et des cellules à prolactine dans l'hypophyse fœetale des bovins. C. R. Acad. Sci., Paris., Sér. D., 272, 433-435.

DUBOIS M. P., 1975. Immunoreactive somatostatin in present in discrete cells of the endocrine pancreas. Proc. nat. Acad. Sci. USA, 72, 1340-1343.

ELLIS S., GRINDELAND R. E., 1973. Diochotomy befween bio- and immunoassayble growth hormone, 409-433. In RAITI S., Advances in human growth hormone research. DHEW Publ. no (NIH), 74-162.

ELLIS S., VODIAN M. A., GRINDELAND R. E., 1978. Studies on the bioassayable growth hormone-like activity of plasma. Recent. Progr. Horm. Res., 34, 213-237.

ERENBERG A., OMORI K., MENKES J. H., OH W., FISHER D. A., 1974. Growth and development of the thyroidectomized ovine fotus. Pediat. Res., 8, 783-789.

FAIRCLOUGH R. J., HUNTER J. T., WELCH R. A. S., PAYNE E., 1975. Plasma corticosteroid concentrations in the bovine foetus near term. J. Endocr., 65, 139-140.

FALCONER I. R., DRAPER S. A., 1968. Thyroid activity and growth, 109-127. In LODGE G. A., LAMMING G. E., Growth and development of mammals. Butterworths, Londres.

FALCONER J., FORBES J. M., HART I. C., ROBINSON J. S., THORBURN G. D., 1977. Somatomedin activity in foetal sheep following hypophysectomy or after reduction of placental size by remo$\mathrm{val}$ of endometrial caruncles. J. Physiol. London, 272, 18P-19P.

FÈVRE J., 1975. Corticostéroïdes maternels et fœetaux chez la truie en fin de gestation. C. R. Acad. Sci. Paris, Sér. D, 281, 2009-2012.

FISHER D. A., DUSSAULT J. H., SACK J., CHOPRA I. J., 1977. Ontogenesis of hypothalamic-pituitarythyroid function and metabolism in man, sheep and rat. Recent. Progr. Horm. Res., 33, 59-116.

FLAIM K. E., LI J. B., JEFFERSON L. S., 1978. Effects of thyroxine on protein turnover in rat skeletal muscle. Am. J. Physiol., 235, E231-E236.

FORBES J. M., DRIVER P. M., EL SHAHAT A. A., BOAZ T. G., SCANES C. G., 1975. The effect of daylength and level of feeding on serum prolactin in growing lambs. J. Endocr., 64, 549-554.

FOWLER D. G., WALLACE A. L. C., BASSETT J. M., 1968. Plasma growth hormone in rams selected for and against skin fold. Proc. aust. Soc. Anim. Prod., 7, 199-203.

FRANK W., RISTOW H. J., HOFFMAN R., GRIMM J., VESER J., 1975. Growth regulation in culfures of embryonic rat fibroblasts by the serum factors S1 and S2. Adv. Metab. Dis., 8, 337-356.

FRYKLUND L., SKOTTNER A., SIEVERTSSON H., HALL K., 1976. Somatomedins A and B. Isolation, chemistry and in vivo effects, 156-168. In PECILE A., MULLER E. E. Growth hormone and related peptides. Excerpla med., Amsterdam.

GIRARD J. R., RIEUTORT M., KERVRAN A., JOST A., 1976. Hormonal control of fetal growth with particular reference to insulin and growth hormone, 197-202. In ROOTH E., BRATTEBY L. E., Perinatal Medicine. Almqvist and Wiksell, Stockholm. 
GLUCKMAN P. D., BRINSMEAD M. W., 1976. Somatomedin in cord blood : relationship to gestational age and birth size. J. clin. Endocr. Metab., 43, 1378-1381.

GLUCKMAN P. D., MUELLER P. L., KAPLAN S. L., RUDOLPH A. M., GRUMBACH M. M., 1979. Hormone ontogeny in the ovine fetus. I. Circulating growth hormone in mid and late gestation. Endocrinology, 104, 162-168.

GOUSSOPOULOS J., 1978. Elude de lo croissance relative postnatale chez le poulet. Principaux tissus ef organes, muscles et os individuels. Influence de l'hypophysectomie. Th. Dr. Univ. Montpellier, $103 \mathrm{pp}$.

GOSPODAROWICZ D., MORAN J. S., MESCHER A. L., 1978. Cellular specificities of fibroblast growth factor and epidermal growth factor, 33-63. In PAPACONSTANTINOU J., RUTTER W. J., Molecular control of proliferation and differentiation. Acad. Press, New York.

GREENSPAN F. S., LI C. H., SIMPSON M. E., EVANS H. M., 1949. Bioassay of hypophyseal growth hormone : the tibia test. Endocrinology, 45, 455-463.

GROSSMAN M. I., 1977. The gastrointestinal hormones : an overview. In JAMES V. H. T., Endocrinology., vol. 2, Excerpta med. Amsterdam.

GUILLEMIN R., 1978. Peptides in the brain : the new endocrinology of the neuron. Science, 202, 390402.

HAFS H. D., PURCHAS R. W., PEARSON A. M., 1971. A review : Relationships of some hormones to growth and carcass quality of ruminants. J. Anim. Sci., 33, 64-71.

HALL K., 1970. Quantifative determination of the sulphation factor activity in human serum. Acta. endocr. Copenh., 63, 338-350.

HALL K., FILIPSSON R., 1975. Correlation between somatomedin A in serum and body height development in healthy children and children with certain growth disturbances. Acta. endocr. Copenh., 78, 239-250.

HAMID M. A., RUBINSTEIN D., FERGUSON K. A., BECK J. C., 1965. The effect of growth hormone and prolactin preparations on the intermediary metabolism of rat adipose tissue. Biochim. biophys. Acta. 100, 179-192.

HAMMOND J., 1932. Growth and the development of mutton qualities in the sheep. Oliver and Boyd, Edinbourg, 597 Pp.

HART I. C., BINES J. A., MORANT S. V., RIDLEY J. L., 1978. Endocrine control of energy metabolism in the cow : comparison of the levels of hormones (prolactin GH, insulin, $\mathrm{T}_{4}$ ) and metabolites in the plasma of high and low yielding cattle at various stages of lactation. J. Endocr., 77, 333345.

HARVEY S., SCANES C. G., 1978. Plasma concentrations of growth hormone during growth in normal and testosterone-treated chickens. J. Endocr., 79, 145-146.

HARVEY S., SCANES C. G., FALCONER J., BOLTON N. J., CHADWICK A., 1977. Variations in levels of growth hormone, prolactin and somatomedin in the circulation during growth in the domestic fowl. J. Endocr., 73, 10P-11P.

HEINRICH U. E., DRAZNIN B., JOHNSON C. J., SCHALCH D. S., 1978. NSILA (non suppressible insulih-like activity) and fetal growth. Int. Symp. on somatomedins and growth. Gêne, Abstr. 47.

HOFFMANN B., WAGNER W. C., GIMENEZ T., 1976. Free and conjugated steroids in maternal and fetal plasma in the cow near term. Biol. Reprod., 15, 126-133.

HONNEBIER W. J., SWAAB D. F., 1974 . Influence of $\alpha$-melanocyte-stimulating hormone $(\alpha-M S H)$, growth hormone $(\mathrm{GH})$ and fetal brain extracts on intrauterine growth of fetus and placenta in the rat. J. Obstet. Gynec. Br. Commonw., 81, 439-447.

HOPKINS P. S., THORBURN G. D., 1972. The effects of fetal thyroidectomy on the development of the ovine fetus. J. Endocr., 54, 55-66.

HURLEY T. W., D'ERCOLE A. J., HANDWERGER S., UNDERWOOD L. E., FURLANETTO R. W., 1977. Ovine placental lactogen induces somatomedin : A possible role in fetal growth. Endocrinology, 101, 1635-1638.

JOAKIMSEN O., BLOM A. K., 1976. Growth hormone concentration in jugular blood plasma in relation to growth rate and age in young bulls. Acta. agric. scand., 26, 239-242.

JOHNS J. T., 1974. The influence of dietary and hormonal factors on growth and development in the ruminant. Ph. D. Thes. Mich. State Univ., E. Lansing. Cité par JOHNS J. T., BERGEN W. G., 1976.

JOHNS J. T., BERGEN W. G., 1976. Growth in sheep. Pre- and post-weaning hormone changes and muscle and liver development. J. Anim. Sci., 43, 192-199. 
JOHNSON L. R., 1977. Gastrointestinal hormones and their functions. Ann. Rev. Physiol., 39, 135-158.

JOST A., 1947. Expériences de décapitation de l'embryon de lapin. C. R. Acad. Sei. Paris, 225, $322-$ 324.

JOST A., 1971. Hormones in development : past and prospects. 1-18. In HAMBURGH M., BARRINGTON E. J. W., Hormones in development. Appleton-Century-crofts, New York.

JOST A., 1977. Le rôle des hormones fœetales dans la croissance du fœetus. J. Physiol. Paris, 73, 877-890.

KAHL S., WRENN T. R., BITMAN J., 1977. Plasma trilodothyronine and thyroxine in young growing calves. J. Endocr., 73, 397-398.

KNIGHT J. W., BAZER F. W., THATCHER W. W., FRANKE D. E., WALLACE H. D., 1967. Conceptus development in intact and unilaterally hysterectomized-ovariectomized gilts : interrelations among hormonal status, placental development, fetal fluids and fetal growth. J., Anim. Sci., 44, 620-637.

KOCHAKIAN C. D., 1965. Mechanism of anabolic action of androgens, 192-213. In KARLSON P., Mechanism of hormone action. Acad. Press, New York.

KOCHAKIAN C. D., 1966. Regulation of muscle growth by androgens, 81-112, In BRISKEY E. J., CASSENS R. G., TRAUTMAN J. C., The physiology and biochemistry of muscle as a food. Univ. Wisc. Press, Madison.

KOSTYO Y. L., KNOBIL E., 1959. The stimulation of leucine $2 \mathrm{C}^{14}$ incorporation into the protein of isolated rat diaphragm by simian growth hormone added in vitro. Endocrinology, 65, 525-527.

KOSUGIYAMA M., KATADA A., KIKUCHI T., 1975. A preliminary report on plasma insulin concentrations on japanese shorthorn and japanese black cattle from birth to 8 weeks of age. Jap. J. zootech. Sci., 46, 374-376.

KRIEG M., VOIGT K. D., 1976. Biochemical substrate of androgenic actions at a cellular level in prostate, bulbocavernosus levator ani and in skelefal muscle. Acta endocr. Copenh., 85, 43-89.

LASCELLES A. K., SETCHELL B. P., 1959. Hypothyroidism in sheep. Aust. J. biol. Sci., 12, 445. Cité par ROBINSON J. S. et al., 1978.

LIGGINS G. C., FAIRCLOUGH R. J., GRIEVES S. A., KENDALL J. Z., KNOX B. S., 1973. The mechanism of initiation of parturition in the ewe. Recent. Progr. Horm. Res., 29, 111-150.

LIGGINS G. C., KENNEDY P. C., 1968. Effects of electrocoagulation of the foetal lamb hypophysis on growth and development. J. Endocr., 40, 371-381.

LISTER D., 1978. Some neuroendocrine aspects of growth, 341-351. In DE BOER H., MARTIN J., 1978. Patterns of growth and development in cattle. Nijhoff M., La Haye.

LUND-LARSEN T. R., BAKKE H., 1975. Growth hormone and somatomedin activities in lines of pigs selected for rate of gain and thickness of backfat. Acta. agric. scand., 25, 231-234.

LUND-LARSEN T. R., SUNDBY A., KRUSE V., VELLE W., 1977. Relation between growth rate, serum somatomedin and plasma testosferone in young bulls. J. Anim. Sci., 44, 189-194.

LUNN P. G., WHITEHEAD R. G., COLE T. J., AUSTIN S., 1979. The relationship between hormonal balance and growth in malnourished children and rats. Br. J. Nutr., 41, 73-84.

MACHLIN L. J., HORINO M., HERTELENDY F., KIPNIS D. M., 1968. Plasma growth hormone and insulin levels in the pig. Endocrinology, 82, 369.

MANCHESTER K. L., 1970. Insulin and protein synthesis, 267-320. In LITWACK G., Biochemical actions of hormones, Vol. 1, Acad. Press, New York.

MANNS J. G., BODA J. M., 1965. Effects of ovine growth hormone and prolactin on blood glucose, serum insulin, plasma nonesterified fatty acids and amino nitrogen in sheep. Endocrinology, 76, 1109-1114.

MARPLE D. N., JUDGE M. D., ABERLE E. D., 1972. Pituitary and adrenocortical function of stress susceptible swine. J. Anim. Sci., 35, 995-1000.

MARTAL J., 1978. Placental growth hormone in sheep : purification, properties and variations. Ann. Biol. anim. Bioch. Biophys., 18, 45-51.

MARTAL J., 1979. Communication personnelle.

MARTAL J., DJIANE J., 1977a. Mammotrophic and growth promoting activities of a placental hormone in sheep. J. Steroid Biochem. 8, 415-417.

MARTAL J., DJIANE J., 1977b. The production of chorionic somatomammotrophin in sheep. J. Reprod. Fert., 49, 285-289.

MAYER M., ROSEN F., 1977. Interaction of glucocorticoids and androgens with skeletal muscle. Metabolism, 26, 937-962. 
MCATEE J. W., TRENKLE A., 1971. Effect of feeding, fasting and infusion of energy sustrates on plasma growth hormone levels in cattle. J. Anim. Sci., 33, 612-616.

MCGUFFEY R. K., THOMAS J. W., CONVEY E. M., 1977. Growth, serum growth hormone, thyroxine prolactin and insulin in calves after thyrotropin releasing hormone or 3-methyl-thyrotropin releasing hormone. J. Anim. Sci., 44, 422-430.

MEGYESI K., KAHN C. R., ROTH J., GORDEN P., 1977. Physiology of nonsuppressible insulin-like activity, 173-177. In : JAMES V. H. T., Endocrinology, Vol. 2, Excerpta med., Amsterdam.

MELLOR D. J., MATHESON I. C., SMALL J., WRIGHT H., 1976. Plasma thyroxine concentrations in ewes and their fetuses during the last six weeks of pregnancy. Res. vet. Sci., 21, 102-103.

NATHANIELSZ P. W., COMLINE R. S., SILVER M., THOMAS A. L., 1973a. Thyroid function in the foetal lamb during the last third of gestation and parturition. J. Endocr., 58, 535.

NATHANIELSZ P. W., SILVER M., COMLINE R. S., 1973b. Plasma tri-iodothyronine concentration in the foetal and newborn lamn. J. Endocr. 58, 683-684.

NICHOLSON M. L., 1976. The effect of anabolic hormones on myoblasts. Th. Syracuse Univ. Ph. D., Xerox Univ. Microfilms, Ann Arbor, Michigan n० 48106, 107 pp.

NISSLEY S. P., RECHLER M. M., 1978. Multiplication-stimulating activity (MSA) : A somatomedin-like polypeptide from culturel rat liver cells. Nat. Cancer Inst. Monogr., 48, 167-177.

OBST J. M., 1974. The relationship between plasma corticoid and growth rate in cattle. Proc. aust. Soc. Anim. Prod., 10, 41-44.

OUTJES D. A., NEY R. L., 1972. Tests of anterior pituitary function. Metabolism, 21, 159-177.

OXENDER W. D., HAFS H. D., INGALLS W. G., 1972. Serum growth hormone, LH and prolactin in the bovine fetus and neonate. J. Anim. Sci., 35, 56-61.

PELLETIER J., 1973. Evidence for photoperiodic control of prolactin release in rams. J. Reprod. Fert., 35, $143-147$.

PETERS R. R., CHAPIN L. T., LEINING K. B., TUCKER H. A., 1978. Supplemental lighting stimulates growth and lactation in cattle. Science, 199, 911-912.

PETERS R. R., TUCKER H. A., 1978. Prolactin and growth hormone responses to photoperiod in heifers. Endocrinology, 103, 229-234.

PIERSON R. W., TEMIN H. M., 1972. The partial purification from calf serum of a fraction with multiplication-stimulating activity for chicken fibroblasts in cell culture and with non-suppressible insulin-like activity. J. Cell Physiol., 79, 319-330.

POSNER B. I., GUYDA H. J., 1976. In : ANTONIADES H. N., Hormones in human blood : detection and assay. Harvard Univ. Press, Cambridge, Mass.

PLIMPTON R. F., OCKERMAN H. W., TEAGUE H. S., GRIFO A. P., CAHILL V. R., 1971. Influence of the time following diethylstilbestrol implantation on the palatability, composition and quality of boar pork. J. Anim. Sci., 32, 41-56.

PURCHAS R. W., MACMILLAN K. L., HAFS H. D., 1970. Pituitary and plasma growth hormone levels in bulls from birth to one year of age. J. Anim. Sci., 31, 358-363.

PURCHAS R. W., PEARSON A. M., HAFS H. D., TUCKER H. A., 1971. Some endocrine influences on the growth and carcass quality of Holstein heifers. J. Anim. Sci., 33, 836-842.

REISFELD R. A., TONG G. L., RICKES E. W., BRINK N. G., STEELMAN S. L., 1961. J. am. Chem. Soc., $83,3717$.

REKLEWSKA B., 1975. Total serum thyroxine concentration during ontogenic development of sheep. Acta. physiol. pol., 26, 139-147.

REYNAERT R., MARCUS S., De PAEPE M., PEETERS G., 1976. Influences of stress, age and sex on serum growth hormone and free fatty acid levels in cattle. Horm. Metab. Res., 8, 109-114.

RIEUTORT M., JOST A., 1976. Growth hormone in encephalectomized rat fetuses, with comments on the effects of anesthetics. Endocrinology, 98, 1123-1129.

RINDERKNECHT E., HUMBEL R. E., 1978a. The amino acid sequence of human insulin-like growth factor I and its structural homology with proinsulin. J. biol. Chem., 253, 2769-2776.

RINDERKNECHT E., HUMBEL R. E., 1978b. Primary structure of human insulin-like growth factor II. FEBS Leff., 89, 283-286.

ROBINSON J. S., HART I., JONES C. T., THORBURN G. D., 1977. Observations on experimental growth-retardation in sheep. Br. J. Obstefr. Gynaecol., 84, 555.

ROBINSON J. S., JONES C. T., CHALLIS J. R. G., THORBURN G. D., 1976. Observations on experimental growth retardation in sheep. Pediatr. Res., 10, 891. 
ROBINSON J. S., KINGSTON E. J., THORBURN G. D., 1978. Physiological and endocrine factors in human fetal growth. Post. grad. med. J., 54, supplem. 1, 51-61.

ROMBAUTS P., 1974. Communication personnelle.

SALMON W. D., 1975. Interaction of somatomedin and a peptide inhibitor in serum of hypophysectomized and starved, pituitary-intact rats. Adv. Met. Dis., 8, 183-199.

SALMON W. D., DAUGHADAY W. H., 1957. A hormonally controlled serum factor which stimulates sulfate incorporation by cartilage in vitro. J. Lab. clin. Med., 49, 825-836.

SALTER J., BEST C. H., 1953. Insulin as a growth hormone. Br. Med. J., 2, 353-356.

SCOW R. O., 1964. Hormonal control of postnatal growth of skeletal muscle. Proc. 2nd. int. Congr. Endocr., Part 2, 772-778.

SHELLEY H. J., 1973. The use of chronically catheterized foetal lamb for the study of foetal metabolism, 360-381. In BARCROFT J., Foetal and neonatal physiology. Cambridge Univ. Press.

SIERS D. G., HAZEL L. N., 1970. Serum growth hormone levels in swine. Growth, 34, 419-430.

SIERS D. G., SWIGER L. A., 1971. Influence of live weight age and sex on circulating growth hormone levels in swine. J. Anim. Sci., 32, 1229-1232.

SITARZ N. E., ERB R. E., MARTIN T. G., SINGLETON W. L., 1977. Relationships between blood plasma testosterone, weaning treatment, daily gains and certain physical traits of young Angus bulls. J. Anim. Sci., 45, 342-349.

SLEBODZINSKI A., 1965. J. Endocr., 32, 45-57. Cité par KAHL S., WRENN T. R., BITMAN J., 1977.

SMITH B., 1964. Histological and histochemical changes in the muscles of rabbits given the corticosteroid triamcinolone. Neurology, 14, 857-863.

SPIELMAN A. A., PETERSEN W. E., FITCH J. B., 1944. J. Dairy Sci., 27, 441. Cité par FALCONER I. R., DRAPER S. A., 1968.

SPURLOCK G. M., CLEGG M. T., 1962. Effect of cortisone acetate on carcass composition and wool characteristics of weaned lambs. J. Anim. Sci., 21, 494-500.

STOKES H., BODA J. M., 1968. Immunofluorescent localization of growth hormone and prolactin in the adenohypophysis of fetal sheep. Endocrinology, 83, 1362-1369.

STRBAK V., TOMSIK F., HLOZANEK I., 1976. Thyroid hormone in serum of fetal calf and pregnan cow during the last trimester of pregnancy. Experientia, 32,1215-1216.

TANNENBAUM G. S., MARTIN J. B., 1976. Evidence for an endogenous ultradian rhythm governing growth hormone secretion in the rat. Endocrinology, 98, 562-570.

TERQUI M., 1978. Contribution à l'étude des æstrogènes chez la brebis ef la truie. Th. Dr. Sci. Paris VI, 115 PP.

THOENEN H., SCHWAB M., OTTEN U., 1978. Nerve growth factor as a mediator of information between effector organs and innervating neurons, 101-118. In PAPACONSTANTINOU J., RUTTER W. J., Molecular control of proliferation and differentiation. Acad. Press, New York.

THORBURN G. D., 1974. The role of the thyroid gland and kidneys in fefal growth. In : Size at birth. Ciba Found. Symp. 27, 185-200. Cité par ROBINSON J. S. et al., 1978.

THORBURN G. D., HOPKINS P. S., 1973. Thyroid function in the foetal lamb. 488-507. In BARCROFT J., Foetal and neonatal physiology. Cambridge Univ. Press.

TRACK N. S., 1977. Evolution of the gastrointestinal hormores, 87-91. In : JAMES V.H. T., Endocrinology, Vol. 2, Excerpta med. Amsterdam.

TRENKLE A., 1969. The mechanisms of action of estrogens in feeds on mammalian and avian growth. In : The use of drugs in animal feeds, publ. 1679, Nat. Acad. Sci., Washington D. C., p. 150. Cité par TRENKLE A., 1970.

TRENKLE A., 1970. Plasma levels of growth hormone, insulin and plasma protein-bound iodine in finishing cattle. J. Anim. Sci., 31, 389-393.

TRENKLE A., 1976. Estimates of the kinetic parameters of growth hormone metabolism in fed and fasted calves and sheep. J. Anim. Sci., 43, 1035-1043.

TRENKLE A., 1977. Changes in growth hormone status related to body weight of growing cattle. Growth, 41, 241-247.

TRENKLE A., IRVIN R., 1970. Correlation of plasma hormone levels with growth and carcass characteristics of cattle. Growth, 34, 313-319.

TRENKLE A., TOPEL D. G., 1978. Relationships of some endocrine measurements to growth and carcass composition of cattle. J. Anim. Sci., 46, 1604-1609. 
TSUSHIMA T., FRIESEN H. G., 1973. Radioreceptor assay for growth hormone. J. clin. Endocr. Metab., 37, 334-337.

TURTON J. D., 1969. The effect of castration on meat production from cattle, sheep and pigs, 1-49. In RHODES D. N., Meaf production from entire male animals. Churchill, Londres.

UNDERWOOD L. E., D'ERCOLE A. J., FURLANETTO R. W., HANDWERGER S., HURLEY T. W., 1978. Somatomedine and growth : a possible role for somatomedin-C in fetal growth. Int. Symp. on somatomedins and growth. Gêne, Abstr. 50.

UTHNE K., 1973. Human somatomedins : purification and some studies on their biological actions. Acto. endocr. copenh., Suppl., 175, 35 pp.

VAN DEN BRANDE J. L., DU CAJU M. V. L., 1973. Plasma somatomedin activity in children with growth disfurbances, 98-115. In RAITI S., Advances in human growth hormone research. DHEW Publ. no (NIH) 74-162.

VAN DEN BRANDE J. L., VAN BUUL S., 1978. The nature of somatomedins and related peptides. Ann. Biol. anim. Bioch. Biophys., 18, 11-19.

VAN WYK J. J., UNDERWOOD L. E., LISTER R. C., MARSHALL R. N., 1973. The somatomedins. A new class of growth-regulating hormones? Am. J. Dis. Child., 126, 705-711.

VAN WYK J. J., UNDERWOOD L. E., HINTZ R. L., CLEMMONS D. R., VOINA S. J., WEAVER R. P., 1974. The somatomedins : a family of insulin-like hormones under growth hormone control. Recent Progr. Horm. Res., 30, 259-318.

VEZINHET A., 1968a. Effet de l'hypophysectomie sur la croissance pondérale de l'agneau. C. R. Acad. Sci. Paris, Sér. D, 266, 388-390.

VEZINHET A., 1968b. Effet de l'hypophysectomie sur la croissance pondérale du lapin. C. R. Acad. Sci. Paris, Sér. D, 266, 2348-2351.

VEZINHET A., 1973. Influence de l'hypophysectomie et de traitements à l'hormone somatotrope bovine sur la croissance relative de l'Agneau. Ann. Biol. onim. Bioch. Biophys., 13, 51-73.

VEZINHET A., 1976. Efude du tissu adipeux chez l'agneau ef le lapin après la naissance : développement, lipolyse, lipogenèse-influence de l'hypophysectomie ef de l'hormone de croissance. Th. Dr. Sci. Montpellier. 167 pp.

VEZINHET A., DAUZIER L., 1970. Influence de traitements à l'hormone somatotrope bovine sur la croissance pondérale d'agneaux normaux ou hypophysectomisés. Ann. Biol. anim. Bioch. Biophys., 10, 5-13.

VIGNOS P. J., GREENE R., 1973. Oxidative respiration of skeletal muscle in experimental corticosteroid myopathy. J. Lab. clin. Med., 81, 365-378.

WAGNER J. F., VEENHUIZEN E. L., ROOT M. A., 1970. Growth hormone in the lamb. J. Anim. Sci., 31, 232-233.

WAGNER W. C., OXENREIDER S. L., 1972. Adrenal function in the cow. Diurnal changes and the effects of lactation and neurohypophyseal hormones. J. Anim. Sci., 34, 630-635.

WALKER D. G., ASLING C. W., SIMPSON M. E., LI C. H., EVANS H. M., 1952. Structural alterations in rats hypophysectomized at six days of age and their correction with growth hormone. Anat. Rec., 144, 19-47.

WALLACE A. L. C., BASSETT J. M., 1970. Plasma growth hormone concentrations in sheep measured by radioimmunoassay. J. Endocr., 47, 21-36.

WOOD J. D., GREGORY N. G., HALL G. M., LISTER D., 1977. Fat mobilization in Pietrain and Large White pigs. Br. J. Nutr., 37, 167-186.

YOUNG J. W., OTCHERE E. O., TRENKLE A., JACOBSON N. L., 1970. Effect of age on glucose, reducing sugars and plasma insulin in blood of milk-fed calves. J. Nutr., 100, 1267.

ZAPF J., RINDERKNECHT E., HUMBEL R. E., FROESCH E. R., 1978a. Nonsuppressible insulin-like activity (NSILA) from human serum : recent accomplishments and their physiologic implications. Metabolism, 27, 1803-1828.

ZAPF J., SCHOENLE E., FROESCH E. R., 1978b. Insulin-like growth factors I and II : Some biological actions and receptor binding characteristics of two purified constituents of nonsuppressible insulin-like activity of human serum. Eur. J. Biochem., 87, 285-296. 